\title{
Some new observations on the cytopathology of fin erosion disease in winter flounder Pseudopleuronectes americanus
}

\author{
Joel E. Bodammer* \\ Department of Fisheries, Animal and Veterinary Science, University of Rhode Island, Kingston, Rhode Island 02881, USA
}

\begin{abstract}
A light and electron microscopic study was conducted on dorsal fin tissues adjacent to acute fin erosion lesions in winter flounder from 2 polluted sites (New York Bight region and New Haven Harbor) on the northeast Atlantic Coast. The objective of this work was to evaluate these minimally affected, lesion-associated tissues which may precede the acute or severe stages of the disease. The following 4 types of pathological conditions were found in the epidermis of diseased fish from the 2 polluted sites: (1) epithelial cell hyperplasia (2) mucous cell hyperplasia and hypertrophy; (3) spongiosis; and (4) focal necrosis. The latter 2 types of lesions have not been previously reported for fin erosion in this species. Changes in the dermis associated with these lesions included fibrosis, abnormal distribution of melanocytes, hyperemia and sclerosis of blood vessels, and hemorrhage. The possibility that hypoxia may play a role in the observed pathology is considered.
\end{abstract}

KEY WORDS: Winter flounder P Pollution - Fin erosion disease $\cdot$ Pathology

\section{INTRODUCTION}

Fin erosion disease in bottom-dwelling species has served as a biomarker for environmental contamination of estuarine and near-shore waters along all coasts of the United States (McCain et al. 1988, O'Connor \& Huggett 1988, Overstreet 1988) and in some locations in Europe (Vethaak 1987, Dethlefsen 1988). A good correlation has been observed between the high prevalence of this disease and contaminated sediments, high levels of contaminants in fish tissues, and other histopathological abnormalities. Winter flounder Pseudopleuronectes americanus demonstrating fin erosion disease have been collected in the waters of the New York Bight (Murchelano \& Ziskowski 1982) and other locations along the northeast coast of the United States (Ziskowski et al. 1987) where the sediments have been shown to be heavily contaminated by a wide variety of pollutants (Zdanowicz et al. 1986, Gronlund et al. 1991, Johnson et al. 1993). In addition, Khan et al. (1992)

'E-mail: jbo0317u@postoffice.uri.edu have observed fin erosion disease in feral winter flounder exposed to bleached kraft mill effluent (BKME).

Murchelano's (1975) observations on the histopathology of severe fin-erosion lesions in winter flounder from the New York Bight revealed that they were most commonly present in the mid-portions of the dorsal and anal fins. He observed a thinning of and loss of epithelium in a distal-proximal direction accompanied by fin-ray degeneration and resorption. In addition, the lesions demonstrated hyperplasia of the epithelium, eosinophilic granular cells (EGC's) and mucous cells. Melanocytes typically observed to be evenly distributed along the epidermal-dermal junction were found to be concentrated in regions where the epithelium was denuded and often located deeply within the dermis in association with blood vessels and nerves Although Murchelano (1975) observed occasional foci of lymphocytic infiltration, no microorganisms could be detected. Changes in the dermis underlying the eroded fins included fibrosis, hyperemia, and hemorrhage. Fibrotic scarring was present in areas where fin degeneration had been severe. The objective of this study was to provide for the first time a light and 
electron microscopic (EM) description of the normal cytology of fin tissues in winter flounder. In addition, through the use of higher resolution methods than those employed by Murchelano (1975), such as the examination of plastic-embedded, 1 to $2 \mu \mathrm{m}$ thick sections by light microscopy and thin sections by EM, it was hoped that a description of the cytopathological changes in tissues adjacent to acute fin-erosion lesions would provide further information on the pathogenesis of this disease, for which there is no presently known etiology in this species.

\section{MATERIALS AND METHODS}

All the fish examined were collected by otter trawl and varied in length from 25 to $40 \mathrm{~cm}$. Thirteen fineroded fish were collected from the New York Bight region which included Raritan or Sandy Hook Bays, NJ in 1974-1975. Seven diseased fish were captured in New Haven Harbor (Morris Cove) during 1987 to 1988, and 4 fish from Great Bay, NJ (a relatively clean site) were sampled as controls during 1975. Four additional control fish were collected in 1992 from the Niantic River (Niantic, CT), a site which had been shown to be minimally contaminated (Gronlund et al. 1991). All flounder having acute fin erosion and non-diseased controls were measured at the time of capture and killed by a blow to the head, and tissue from the tip of the dorsal fin adjacent to well-established, severe lesions found in diseased fish, as well as comparably located tissue (i.e., tip of the dorsal fin) from control fish was excised and prepared for microscopy as described below. A piece of distal fin tissue approximately $5 \mathrm{~mm}$ in thickness and $10 \mathrm{~mm}$ in length was removed from both the fin-eroded and control fish and placed on a piece of dental wax. It was then carefully divided into small pieces (4 to 6 ) containing at least 2 fin rays per segment, which were placed in fixative.

All tissues taken from fish captured in the New York Bight region and Great Bay were fixed in ice cold 10 to $4^{\circ} \mathrm{C}$ ), $4 \%$ glutaraldehyde in $0.1 \mathrm{M}$ phosphate buffer at a pH of 7.4 for at least $24 \mathrm{~h}$ and kept refrigerated until further processing, which was completed no later than 1 wk after collection. Microscopic examination of these tissues indicated that this fixative might be slightly hypertonic (e.g., red blood cells [RBCs] slightly crenated). Therefore, all tissues from New Haven Harbor fish were fixed in $2 \%$ glutaraldehyde using the identical buffer and procedure as stated for the New York Bight region and Great Bay specimens. Control tissues from Niantic River fish were fixed in both 2 and $4 \%$ glutaraldehyde in the same buffer as mentioned above. Subsequent to primary fixation all fin tissues were washed 4 times in $0.1 \mathrm{M}$ phosphate buffer $(\mathrm{pH}$
7.4) and acclimated to room temperature before postfixation for $1 \mathrm{~h}$ in $1 \%$ osmium tetroxide in $0.1 \mathrm{M}$ phosphate buffer at pH 7.4. The tissues were then dehydrated in a graded series of ethanols, including 2 washes in $100 \%$ ethanol and 4 washes in propylene oxide. Next, the tissues were infiltrated and embedded in Spurr's (1969) resin. Thick sections were cut from no less than 4 blocks for each control or fin-eroded fish at 1 to $2 \mu \mathrm{m}$ with glass knives and stained with toluidine blue dye. Because no decalcifying agents were employed, thick sections were not taken through the fin rays, but as close as possible to them. Light microscopic examination of thick sections permitted both photomicrography and selection of fields to be thinsectioned $(60$ to $90 \mathrm{~nm})$ with diamond knives. Thin sections were stained with alcoholic $(50 \%)$ uranyl acetate and lead citrate before examination, and electron micrographs were taken with a Zeiss EM9 S2 electron microscope.

All of the 4 to 6 pieces from each fish were examined for pathological abnormalities. If any of the fin pieces from a given fish demonstrated a particular abnormality, the fish was scored positive for that abnormality with regard to the data expressed in Table 1.

\section{RESULTS}

\section{Observations on control fish}

The stratified squamous epithelium on the fins of winter flounder was principally composed of a superficial layer of variably shaped epithelial cells which frequently stained metachromatically with toluidine blue dye (Figs. 1 \& 2). A middle layer of epithelial cells typically oval to elongate in appearance was several cells thick and a basal layer of cuboidal or columnar cells

Table 1. Lesions associated with fin erosion in winter flounder (stated as percent of total). No significant difference was found for any lesion type upon comparing the results from the control versus the contaminated sites using the Fisher Exact Test (2-tailed). NYB: New York Bight region (a contaminated site), NHH: New Haven Harbor, CT (a contaminated site), GTB: Great Bay, NJ (a control site), NTR: Niantic River, CT (a control site)

\begin{tabular}{|lcccc|}
\hline Type & $\begin{array}{c}\text { NYB } \\
(\mathrm{n}=13)\end{array}$ & $\begin{array}{c}\text { NHH } \\
(\mathrm{n}=7)\end{array}$ & $\begin{array}{c}\text { GTB } \\
(\mathrm{n}=4)\end{array}$ & $\begin{array}{c}\text { NTR } \\
(\mathrm{n}=4)\end{array}$ \\
\hline Focal necrosis & 61 & 43 & 25 & 25 \\
Epithelial hyperplasia & 23 & 71 & 25 & 0 \\
Spongiosis & 54 & 57 & 0 & 25 \\
Mucous cell hyperplasia & 39 & 85 & 25 & 0 \\
Blood vessel congestion & 92 & 57 & 0 & 0 \\
Hemorrhage & 46 & 43 & 0 & 0 \\
& & & & \\
\hline
\end{tabular}




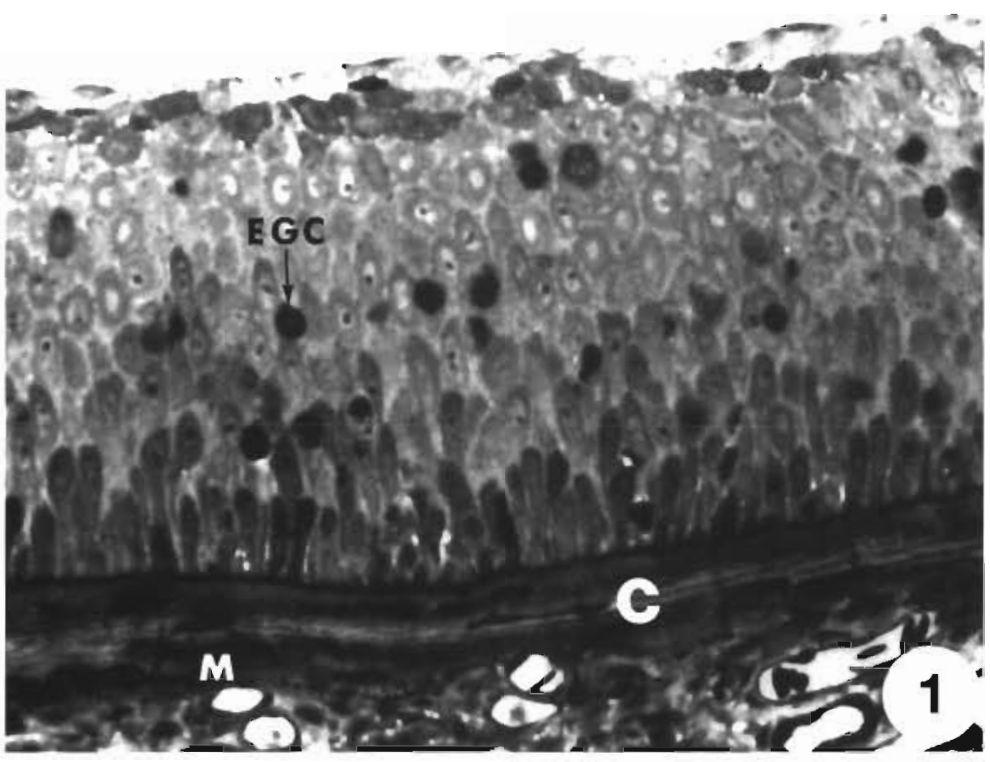

Fig. 1 Photomicrograph of the fin epithelium (pigmented side) from a control fish (Great Bay) near the fin rays. Note the melanophores (M) within the thick collagen band ( $\mathrm{C}$ ) below the well-defined basement membrane $(\mathrm{EGC}=$ eosinophilic granular cell) $\times 473$ cytoplasm contained apical, dense layers of fine filaments, an oval nucleus with marginated heterochromatin, a well-developed Golgi complex and an endoplasmic reticulum system (ERS), plus numerous vesicles which in some instances (Fig. 4) appeared to be released at their apical plasmalemma. At their apical borders the surface epithelial cells shared junctional complexes. Numerous desmosomes were observed between these cells along their lateral and basal cell membranes. The epithelial cells in the middle layer were typically oval to elongate in shape and had centrally placed, rounded nuclei with prominent nucleoli (Fig. 5). The cytoplasm of these cells was electron dense owing mainly to the large number of fine filaments which communicated with the numerous desmosomes found around the cells' periphery. The round to oval-shaped mitochondria and elements of the ERS were frequently observed in close proximity to the cell's nucleus. In addition to numerous desmosomes, these cells also had marginal resting on a well-developed basement membrane was also present. Densely staining, oval, eosinophilic granular cells as originally described by Roberts et al. (1971) for the plaice Pleuronectes platessa were located in the basal or middle cell layer (Figs. 1 \& 2), and mucous cells were interspersed at the epidermal surface (Fig. 2). The epithelium of the skin in close proximity to the fin rays was typically thicker ( 40 to $60 \mu \mathrm{m}$ ) than that found between the rays ( 20 to $35 \mu \mathrm{m}$ ), but no difference in cell types was present. Further, no difference in cell type or composition was noted for the epidermis upon comparing the pigmented and non-pigmented sides of the fin tissues. Immediately below the basal cells a prominent and often undulating basement membrane was found, which signaled the beginning of the dermis, and subjacent to it thick bands of collagen fibers $\left(C_{\text {; }}\right.$ Figs. 1 \& 2) were observed.

When observed by electron microscopy, the surface epithelium was a layer of effete, electron lucent cells, with scattered cells sloughing from the surface (EC; Fig. 3). Immediately below the surface layer of effete cells were pleomorphic, electron dense cells (Figs. $3 \& 4$ ) that bore the typical microridges reported for many species of teleosts (Whitear 1986a). Their

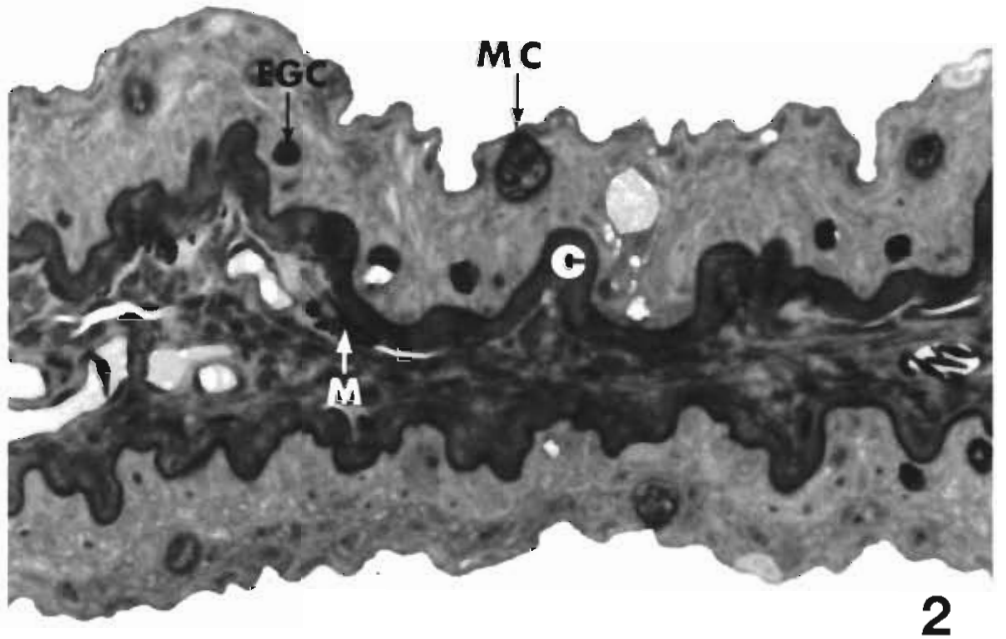

Fig. 2. Photomicrograph of the fin epithelium from a control fish (Niantic River) midway between a pair of fin rays. The basement membrane and associated collagen band $(\mathrm{C})$ have a distinctly scalloped appearance. A mature mucous cell (MC) is observed at the epithelial surface. (EGC = eosinophilic granular cell; $\mathrm{M}=$ melanophore $) \times 467$ 


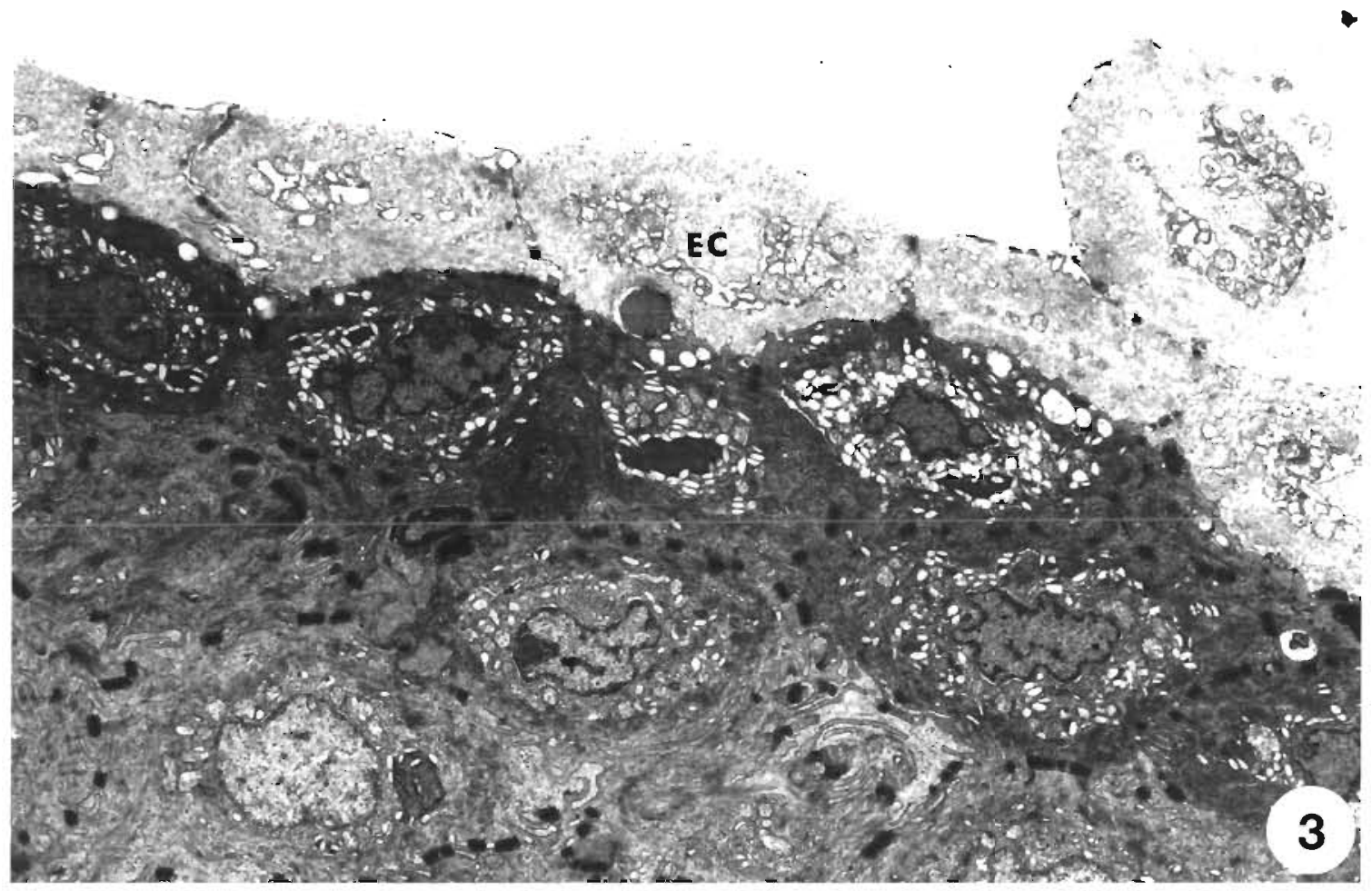

Fig. 3. Electron micrograph of the surface epithelium of a control fish (Niantic River) illustrating the effete, desquamating cells $(\mathrm{EC})$ and the dense vesiculated cells below them. $\times 4370$

the basal cells contained organelles similar to the cells found in the middle layer, but these were more uniformly dispersed throughout the cytoplasm. Ovalshaped eosinophilic granular cells having eccentrically located nuclei and numerous dark granules and small lymphocytes, sometimes containing electron-dense granules, were frequently found among the basal cells (Fig. 7). Mucous cells were not observed in the basal cell layer.

On the flounder's pigmented or eyed side (Fig. 8), melanophores were located in the dermis either within or slightly below the dense band of connective tissue beneath the basement membrane (Fig. 8). In areas close to the fin rays, the stratum spongiosum beneath the thick band of collagen was composed of a loose, connective-tissue matrix that mainly contained capillaries and small groups of nerves. The stratum compactum in this area contained larger blood vessels and nerves embedded in dense connective tissue. The hypodermis, in this instance, could not be clearly identified. The dermis in the inner fin tissue between the rays, as shown in Fig. 2, was a more uniform layer of loose connective tissue containing small blood vessels, nerves, and a few melanophores.

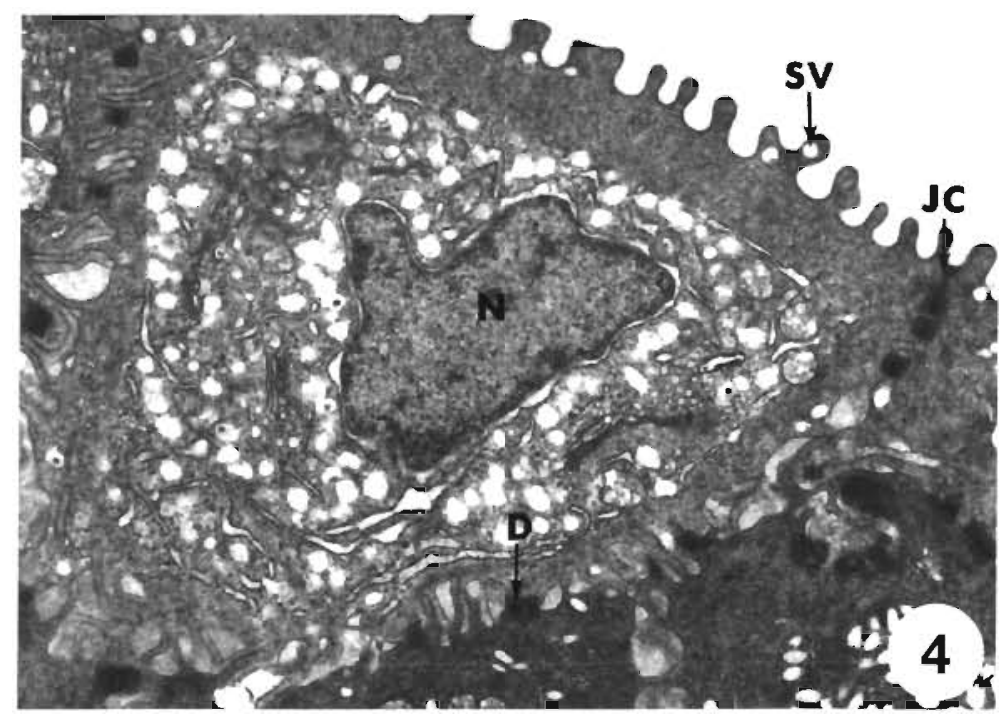

Fig. 4. Electron micrograph of a vesiculated cell from a control fish (Niantic River) demonstrating their apical, microridge borders and the secretory nature of their cytoplasm. Note the secretory vesicles (SV) within the microridge projections at the cell surface. Junctional complexes (JC) are present between cells at their apical borders and desmosomes (D) were found on their lateral and basal borders. $(\mathrm{N}=$ nucleus $) \times 8167$ 


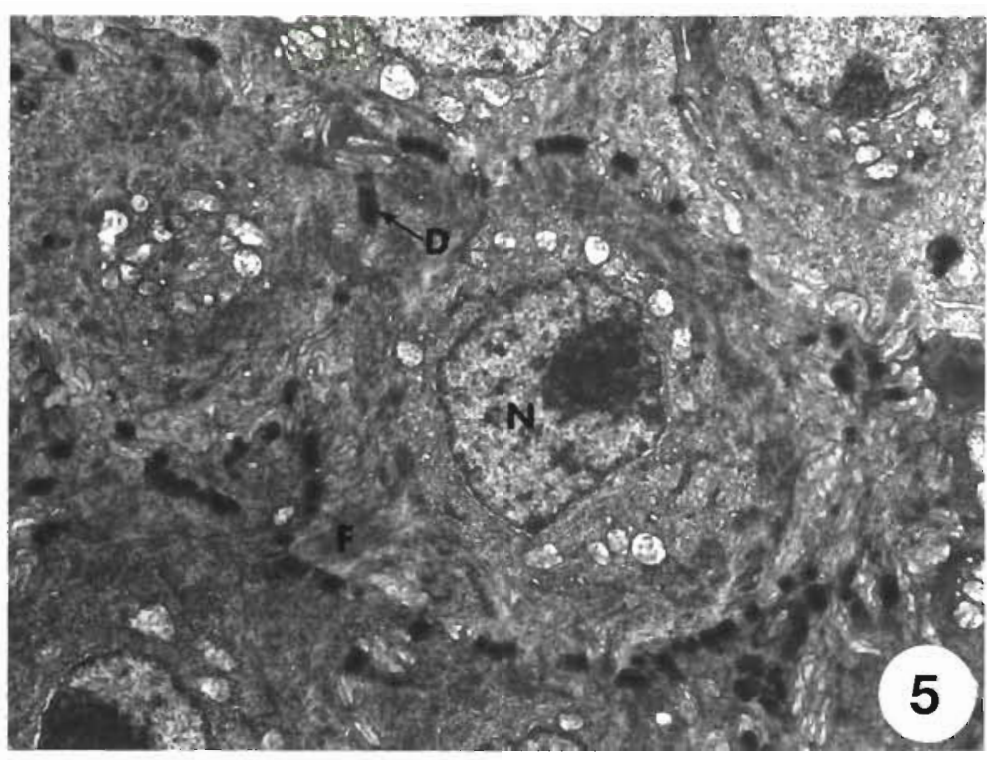

Fig. 5. Electron micrograph of a mid-level epithelial cell from a control fish (Great Bay). Note the dense, filamentous cytoplasm $(F)$ around the cell's periphery, and the desmosomal junctions (D) between adjacent cells. ( $N=$ nucleus) $\times 6285$

\section{Observations on diseased fish}

Six types of abnormalities were commonly observed in the fin tissues of diseased fish from either the New York Bight region or New Haven Harbor (Table 1). Owing to the small sample size, no significant difference was observed for the prevalence of any lesion type upon comparing the results from the control versus the contaminated sites after applying the Fisher Exact Test (2-tailed).

\section{Epithelial and mucous cell hyperplasia}

In areas between the fin rays where the normal skin often had a folded configuration, the hyperplastic epidermis frequently demonstrated an irregular, villus-like shape (Fig. 9). A greatly increased number of mucous cells, many of which appeared to be hypertrophic or empty (spent), were sometimes present. Eosinophilic granular cells were also found (EGC ${ }_{i}$ Fig. 9) scattered throughout the hyperplastic tissue but did not appear to be in greater numbers in the hyperplastic epithelium of fish from the contaminated sites when compared with the epithelium of fish from control sites. The epidermis in fin tissue near the fin rays (Fig. 10) was thickened (e.g., 200 to $300 \mu \mathrm{m}$ ) and in some instances represented a 4 - to 5-fold increase in height from that of normal skin. Occasionally, melanomacrophages as well as mucous cells were found at the surface of the epithelium. In all instances, the hyperplastic foci lacked the stroma or dermal papillae described for epidermal papillomas (Peters 1984, Smith et al. 1989).

\section{Spongiosis}

Epidermal and mucous cell hyperplasia was frequently observed to be accompanied by spongiosis (intercellular edema) as defined for fish integument by Roberts \& Bullock (1976) and Roberts (1989). When present in the epithelium in close proximity to the fin rays, the epithelial cells in the middle epidermal layer had either an oval (Fig. 11) or elongate (squamous) shape (Fig. 12). The abnormally large extracellular spaces permitted one to visualize the spinous processes between the affected cells. The basal cells and surface cells remained more or less intact. In the thinner fin tissue between the rays (Fig. 13), spongiotic lesions in the epithelium were more limited in scope and demonstrated widened intercellular spaces which had a cleft-like appearance. Frequently, the underlying blood vessels within the dermis were hyperemic.

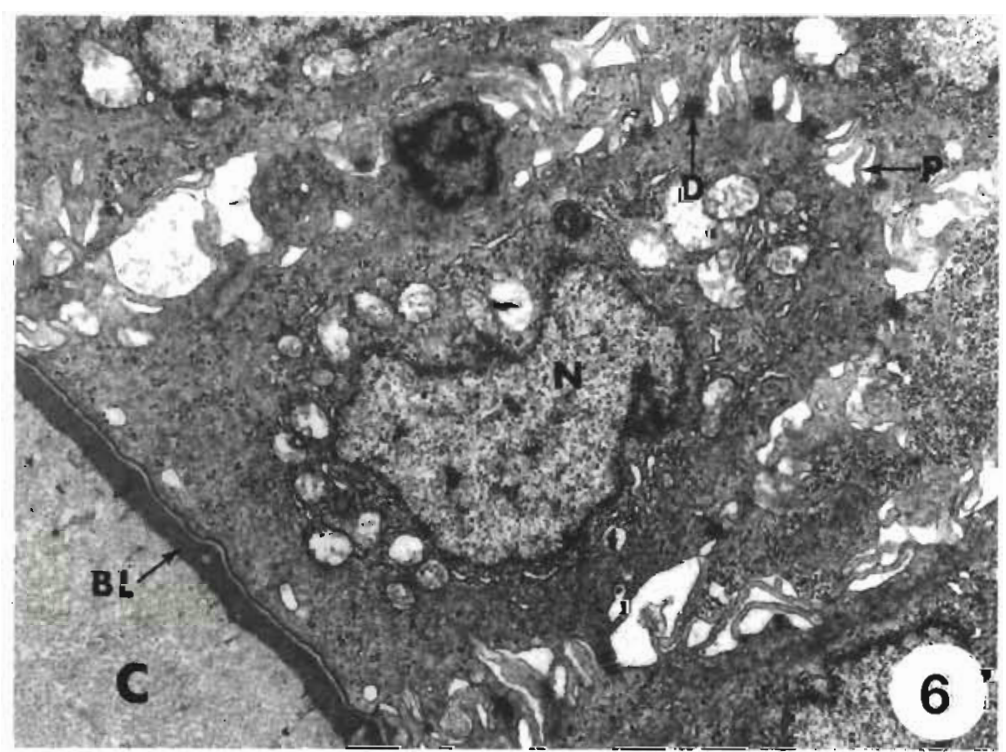

Fig. 6. Electron micrograph of a columnar-shaped basal cell from a control fish (Great Bay) that was separated from a large band of collagen (C) by a prominent basal lamina (BL). Like the epithelial cells found in middle layer of the epithelium, the basal cells had numerous plicae $(P)$ on their surfaces and desmosomal junctions (D) were readily observed between them. $(\mathrm{N}=$ nucleus $) \times 7550$ 


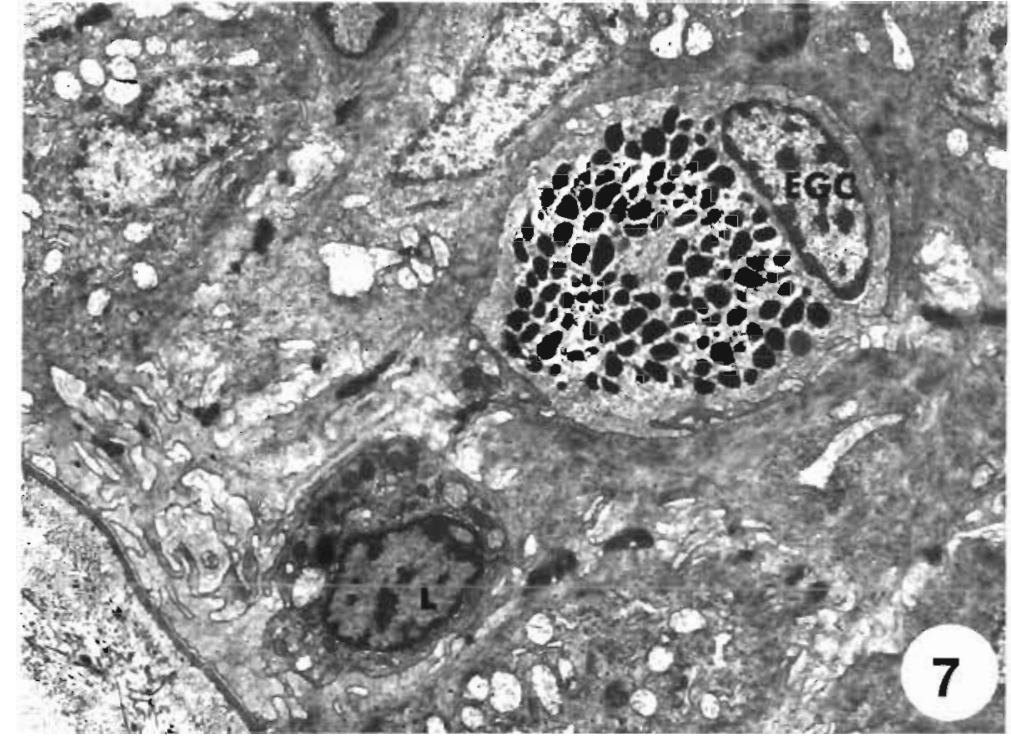

Fig. 7. Electron micrograph of the basal border of the fin epithelium from a control fish (Niantic River) in which a lymphocyte (L) and eosinophilic granular cell (EGC) can be seen amongst the epithelial cells. $\times 5971$

regions containing either oval (Fig. 14) or squamous cells (Fig. 15) that were in the beginning stages of degeneralion. Sometimes, the intercellular spaces between these cells contained an amorphous material of low electron density (Fig. 14) and the cellular processes of the epithelial cells frequently exhibited multiple and/or fused desmosomal junctions. Within the cytoplasm of these cells, some changes associated with cell death, such as enlarged mitochondria, moderate vacuolation, and accumulation of glycogen, were observed. Pathological changes within necrotic cells present in spongiotic tissues (Figr. 16) included the following: (1) vesiculate nuclei; (2) high amplitude mitochondrial swelling and loss of cristae; (3) a breakdown and/or condensation of the highly ordered cytoplasmic filaments; (4) extensive vacuolation; (5) vesiculation of the plasmalemma and loss of cytoplasmic components, particularly glycogen, to the

EM evaluation of spongiotic lesions within the middle layer of fin epithelium near the fin rays demonstrated an increase in intercellular space (edema) in intercellular space; and (6) a loss of integrity of desmosomal junctions between epithelial cells. Ultrastructural observations of spongiotic changes in the thinner,

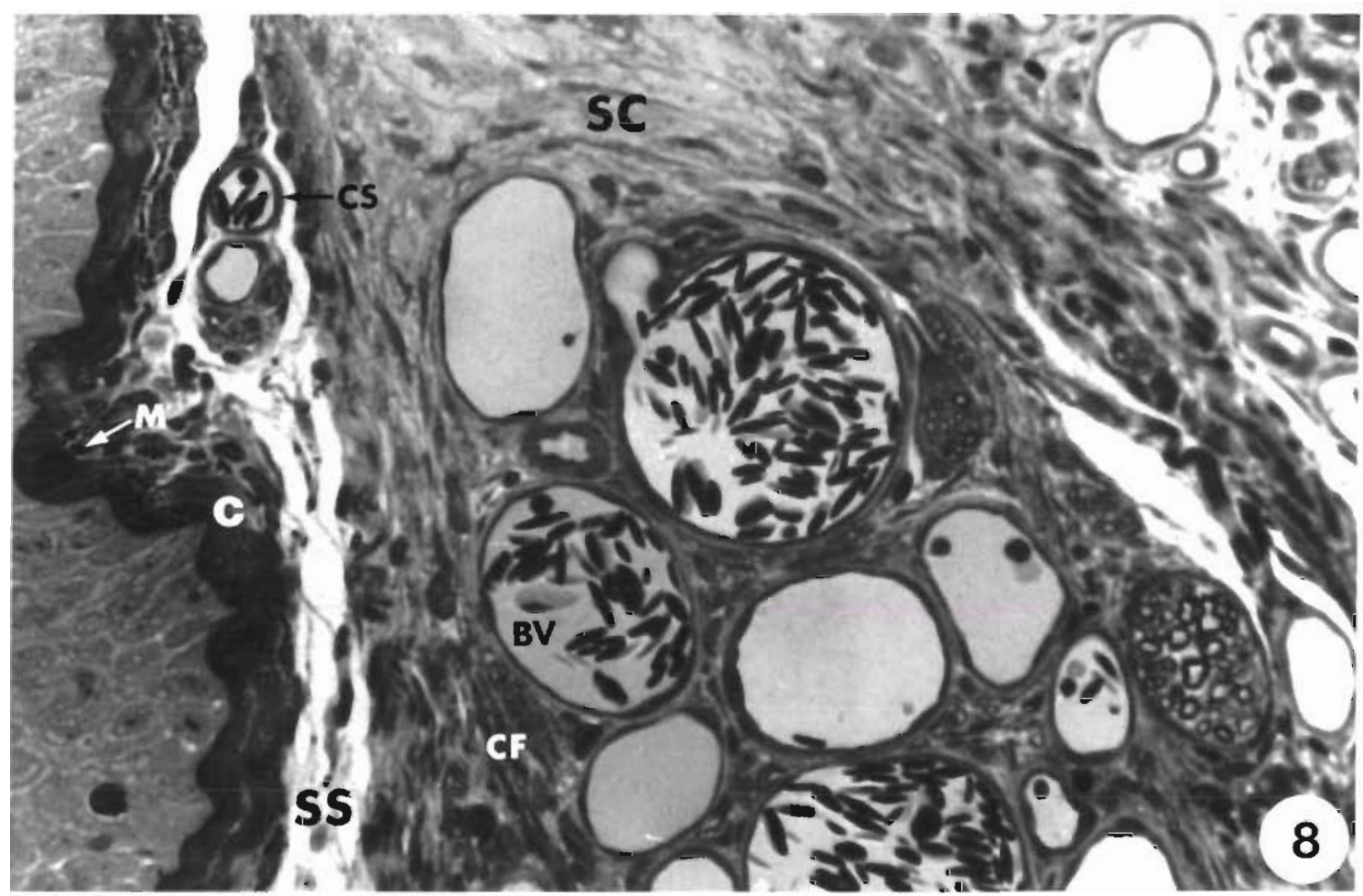

Fig. 8. Photomicrograph of the dermis from a control fish (Niantic River) illustrating the dense collagen. band (C) immediately below the fin epithelium, and the presence of melanophores (M), capillaries (CS), and loose connective tissue within the stratum spongiosum (SS). Deeper within the dermis, the stratum compactum (SC) was composed of dense, collagen fibers (CF), larger blood vessels $(\mathrm{BV})$ and nerves. $\times 520$ 


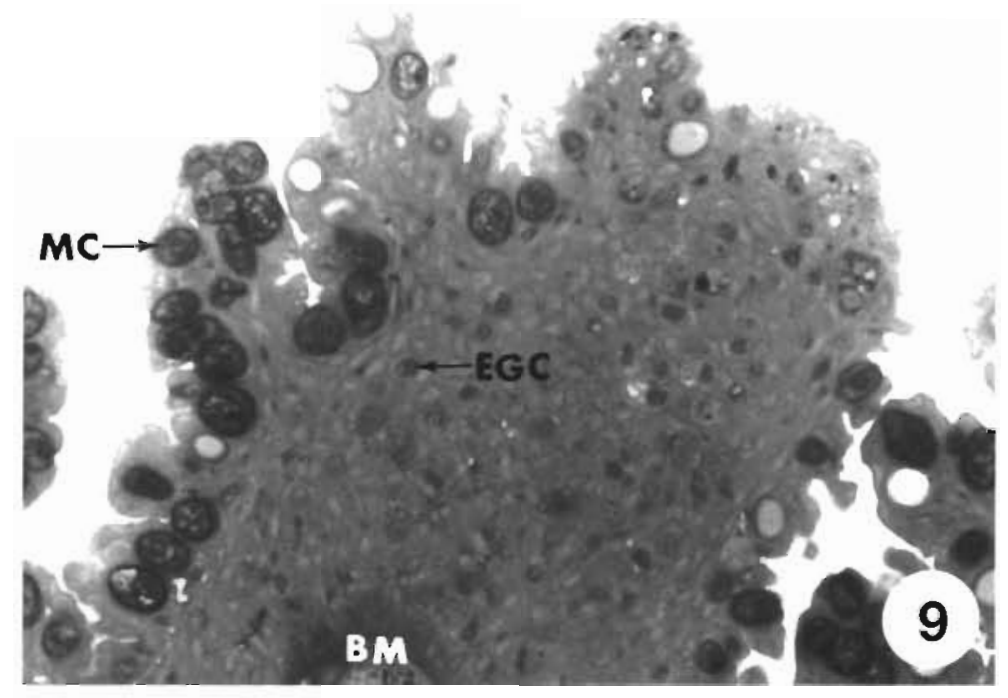

Fig. 9. Photomicrograph of epidermal and mucous cell hyperplasia (MC) from a fish from a contaminated site (New Haven Harbor) is shown in a folded portion of the fin distant from the fin rays. A number of empty (spent) and hypertrophied mucous cells are present. (EGC = eosinophilic granular cell; $\mathrm{BM}=$ basement membrane) $\times 241$

\section{Focal necrosis}

Necrotic regions of limited dimension within the fin epithelium differed from the pathological conditions described above in that they always involved the death and disruption of the surface epithelial cells. In fin tissues close to the rays (Fig. 20), necrosis and sloughing were observed at the epithelial surface and were sometimes accompanied by cell death and necrosis in the middle layer of the epidermis. In fin tissues distant from the rays (Fig. 21), the epidermis of diseased fish sometimes had a villus-like configuration and the surface epithelial cells were swollen and necrotic. In some instances, the epithelial cells within the epidermis demonstrated nuclear pyknosis. Densely staining EGC cells were both numerous and distributed throughout the epithelium. Necrotic changes observed in focal necrotic lesions were not accompanied by marked leucocytic infiltration. inter-ray tissue (Fig. 17) confirmed the presence of abnormally large, cleft-like intercellular spaces (as previously shown in Fig. 13) and revealed degenerating cells at both the mid-and basal levels undergoing nuclear pyknosis.

\section{Pathological changes in the dermis}

Modification of the epidermal-dermal junction resulting in either the disruption and/or loss of the basement membrane was frequently observed in association with areas of epithelial hyperplasia $(\leftarrow$; Fig. 18). The loss of basement membrane integrity was often accompanied by the aggregation of melanocytes at this border and dermal fibrosis within the underlying connective tissue. In addition, congestion of numerous small blood vessels by red blood cells (hyperemia) and hemorrhaging were also observed within the fibrotic dermis. At an adjacent but slightly deeper site within the affected dermis (Fig. 19) in the same fish, melanocytes and large numbers of extravasated blood cells were observed within the fibrotic dermis and the blood vessels were surrounded by sclerotic tissue and closely associated melanocytes.

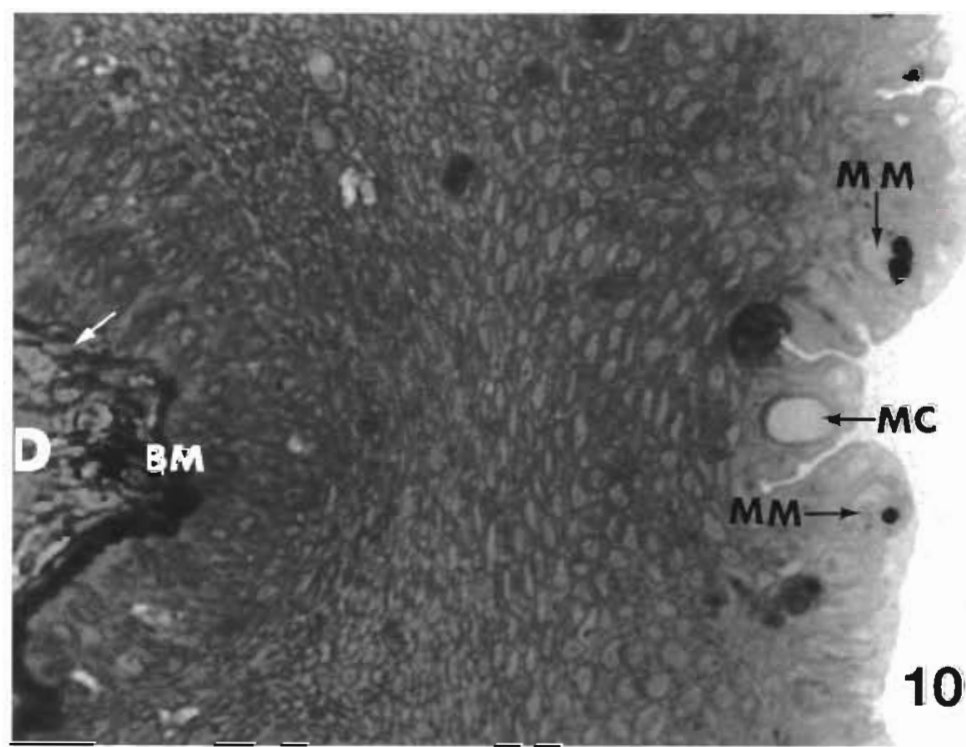

Fig. 10. Photomicrograph of epidermal hyperplasia in the fin epithelium in close proximity to the fin rays found in a fish from a contaminated site (New York Bight). Melanomacrophages (MM) as well as depleted mucous cells (MC) could be found at the surface of the epithelium. The undulating basement membrane $(\mathrm{BM})$ was uneven in thickness and appeared to be disrupted $(\leftarrow) \cdot(\mathrm{D}=$ dermis $) \times 352$ 


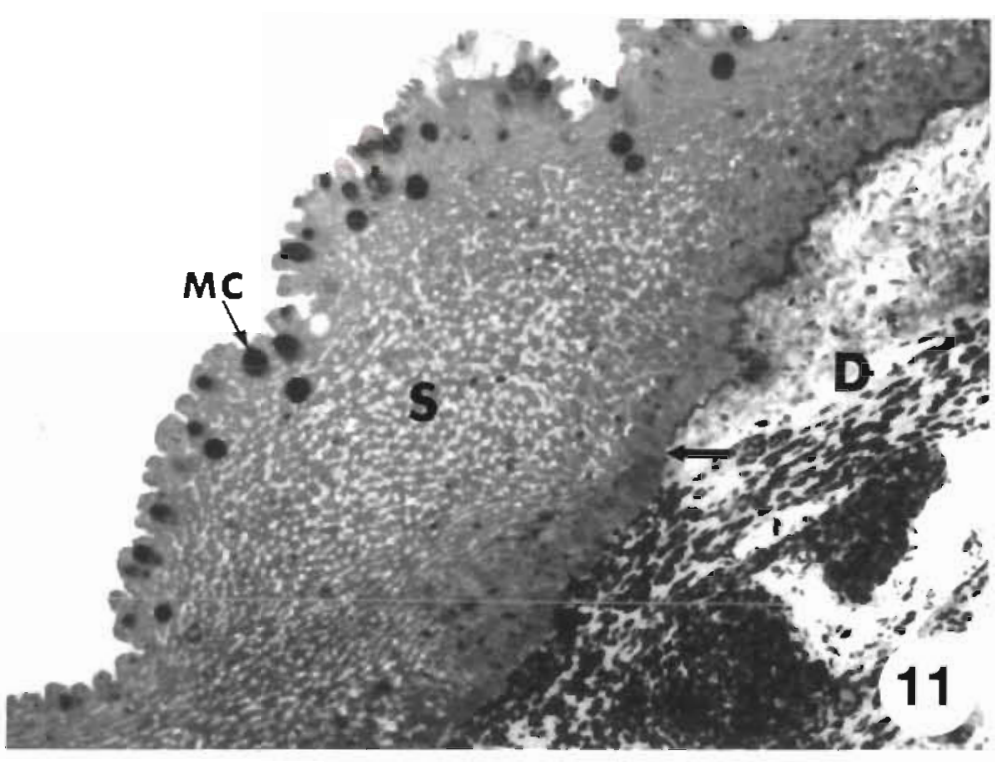

Fig. 11. Photomicrograph of spongiosis (S) in the hyperplastic fin epithelium near the fin rays from a fish collected at a contaminated site (New York Bight). Note the hyperplasia of the mucous cells (MC) at the epidermal surface, the disruption of the basement membrane $(\leftarrow)$ and the hyperemia and hemorrhage within the dermis (D). $\times 153$

mast cells and have been shown to degranulate when stimulated by bacterial extracellular products (Ellis 1985) or neurotransmitters (Powell et al. 1991).

The dermis in normal fin tissue of winter flounder was not well organized into a stratum spongiosum, stratum compactum, and hypodermis as has been described for the skin of other fish species (Bullock \& Roberts 1974, Whitear 1986b). The stratum spongiosum and stratum compactum and the structures they typically include were found only in close proximity to the fin rays, but were not present in the thinner tissue between the rays. Comparison between the structure of the dermis observed for the fin tissues in winter flounder and that for other fish species was difficult, as the author was unable to find a thorough histological description of the dermis underlying the fin tissues of other species. Typically, morphological studies on the fins of fish have focused on the histology of the lepidotrichia and their associated structures (Lanzing 1976, Becerra et al.

turally similar to the skin of the plaice (Roberts et al. 1971), except that the irregularities in thickness observed for the epidermis found on the dorsal fin of the plaice were not observed in this species. Unlike the surface epithelial cells described for the plaice, however, those in the dorsal fin tissues of winter flounder stained metachromatically with toluidine blue dye, indicating the presence of acidic glycoproteins (Clark 1981), and appeared to be secretory based on the fine structural nature of their cytoplasm. Thus, these cells may provide secretions that bathe the skin as has been described by Whitear \& Mittal (1984) for the blenny Blennius pholis (L.) and for several species of Indian carp (Singh \& Mittal 1990). Lymphocytes routinely found in the fin epithelium of winter flounder, but not described in the plaice, may be involved in the generation of antibacterial immunoglobulins found in the skin mucous of other fish species (Peleteiro \& Richards 1985, Alexander \& Ingram 1992). Eosinophilic granular cells (EGCs), structurally similar to those described in the skin of the plaice (Roberts et al. 1971), were regularly observed in the dorsal fin epithelium of winter flounder. Morphologically similar cells have been extensively studied in salmonids where they are believed to be analogous to mammalian
1983, Brandstätter et al. 1990) which were not studied herein

Studies of the New York Bight region $\left(\mathrm{O}^{\prime}\right.$ Connor \& Rachlin 1982, O'Connor et al. 1982, Zdanowicz et al. 1986, Johnson et al. 1993) and New Haven Harbor (Greig et al. 1977, Greig \& Sennefelder 1987, Gronlund

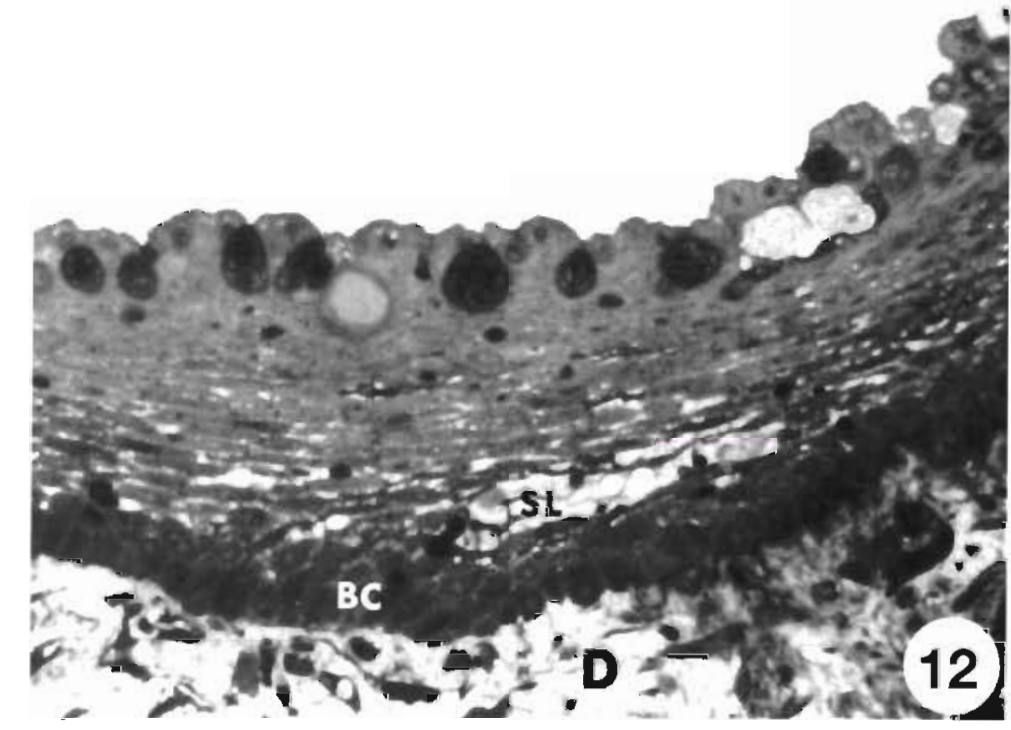

Fig. 12. Photomicrograph of a spongiotic lesion (SL) amongst horizontally oriented epithelial cells in the middle layer of fin tissue near the fin rays found in a fish from a contaminated site (New Haven Harbor). The lesion lies immediately above the basal cells $(\mathrm{BC})$ which have a 'tombstone-like' appearance, and the basement membrane is absent. $(D=$ dermis $) \times 342$ 


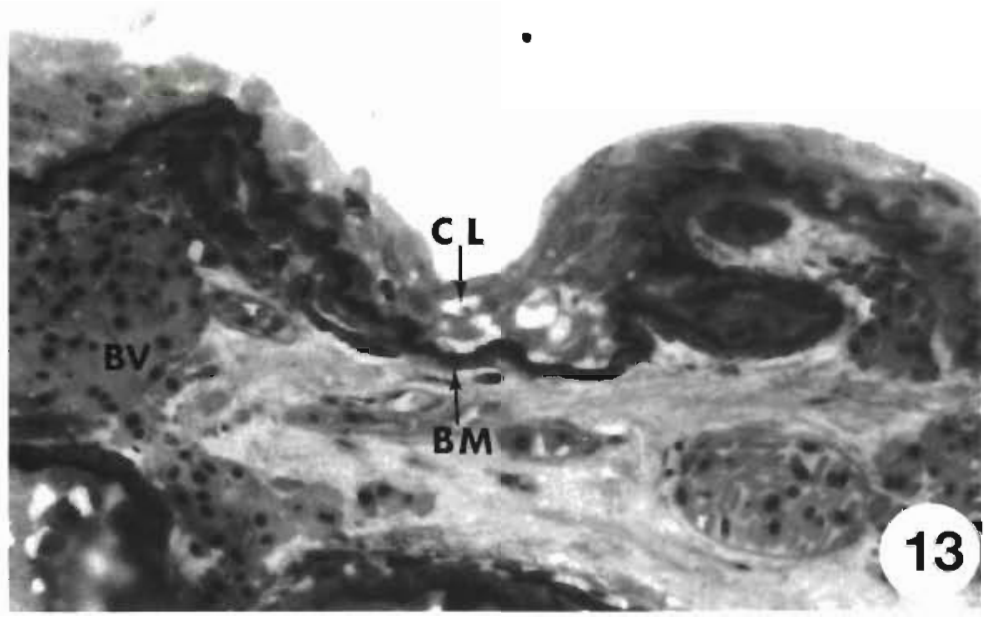

Fig. 13. Photomicrograph of a spongiotic lesion in the fin epithelium between the fin rays in a fish from a contaminated site (New Haven Harbor) demonstrating a widened intercellular space within the epidermis that had a cleft-like (CL) appearance. Note the congested blood vessels (BV) within the dermis. ( $\mathrm{BM}=$ basement membrane) $\times 342$

et al. 1991, Robertson et al. 1991, Turgeon \& O'Connor 1991, Johnson et al. 1993) have clearly shown that the diseased fish examined in this study were collected from some of the most polluted areas along the northeast coast of the United States. Both of these sites are heavily contaminated with a wide variety of anthropogenic substances and various types of liver lesions have been reported in winter flounder collected from them (Murchelano \& Wolke 1985, Gronlund et al. 1991, Johnson et al. 1993).

Unlike fish from the polluted sites mentioned above, winter flounder from the Great Bay control site off the southern New Jersey coast have not demonstrated high fin erosion disease prevalence (Ziskowski et al. 1987), liver lesions, or high contaminant levels in the sediments (Zdanowicz et al. 1986, Johnson et al. 1993). Similarly, the Niantic River, from which control tissues were also taken for this study, has been shown to be a minimally contaminated region of Long Island Sound (Gronlund et al. 1991).

Roberts \& Bullock (1976) and Roberts (1989) have indicated that epidermal hyperplasia in fish results in the addition of cells at all levels of the epithelium and may be caused by a variety of factors including chemical pollutants. The observations reported herein regarding epidermal hyperplasia, melanophore aggregation, and dermal fibrosis are in good agreement with earlier histopatho-

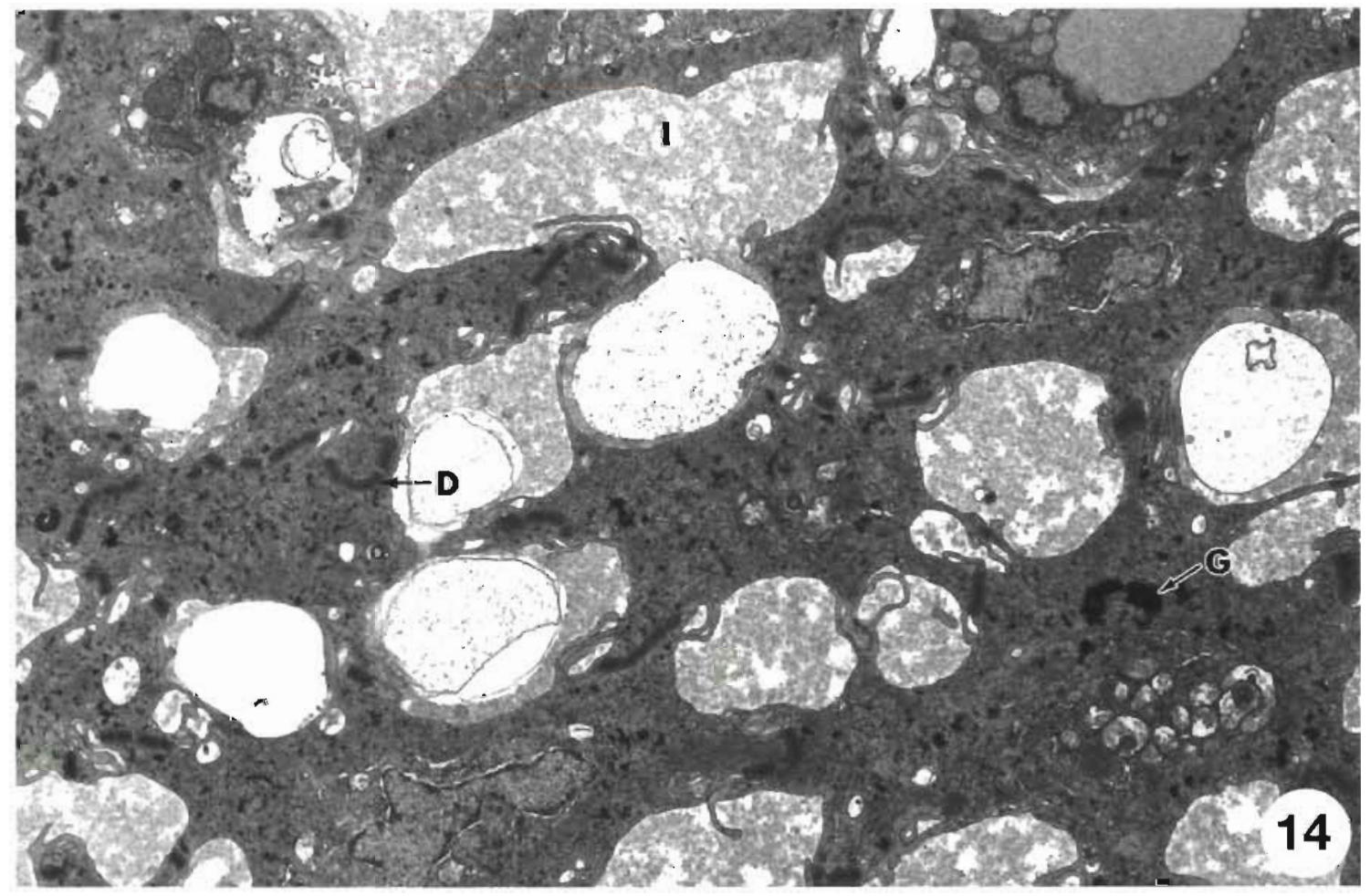

Fig. 14. Electron micrograph of the middle epithelial layer of oval-shaped cells near a fin ray from a fish collected at a contaminated site (New York Bight) that demonstrates the early signs of spongiosis. $(\mathrm{D}=$ desmosomes; $\mathrm{I}=$ intercellular space; $\mathrm{G}=$ glycogen) $\times 5278$ 


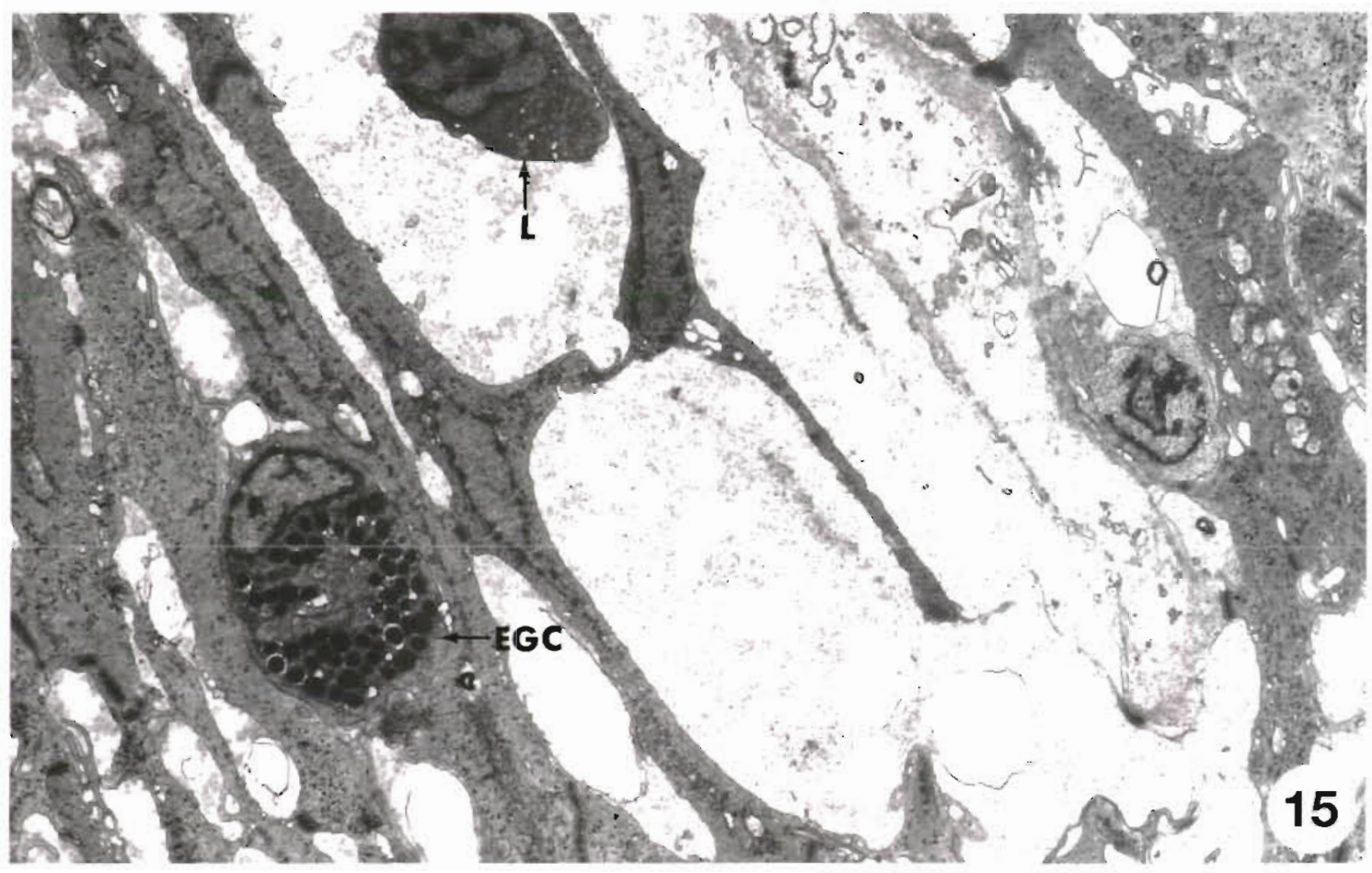

Fig. 15. Electron micrograph of a spongiotic lesion in the middle epithelial layer of squamous cells near a fin ray from a fish collected at a contaminated site (New York Bight). Note the eosinophilic granular cell (EGC) and lymphocyte (L) in the expanded extracellular space. $\times 5278$

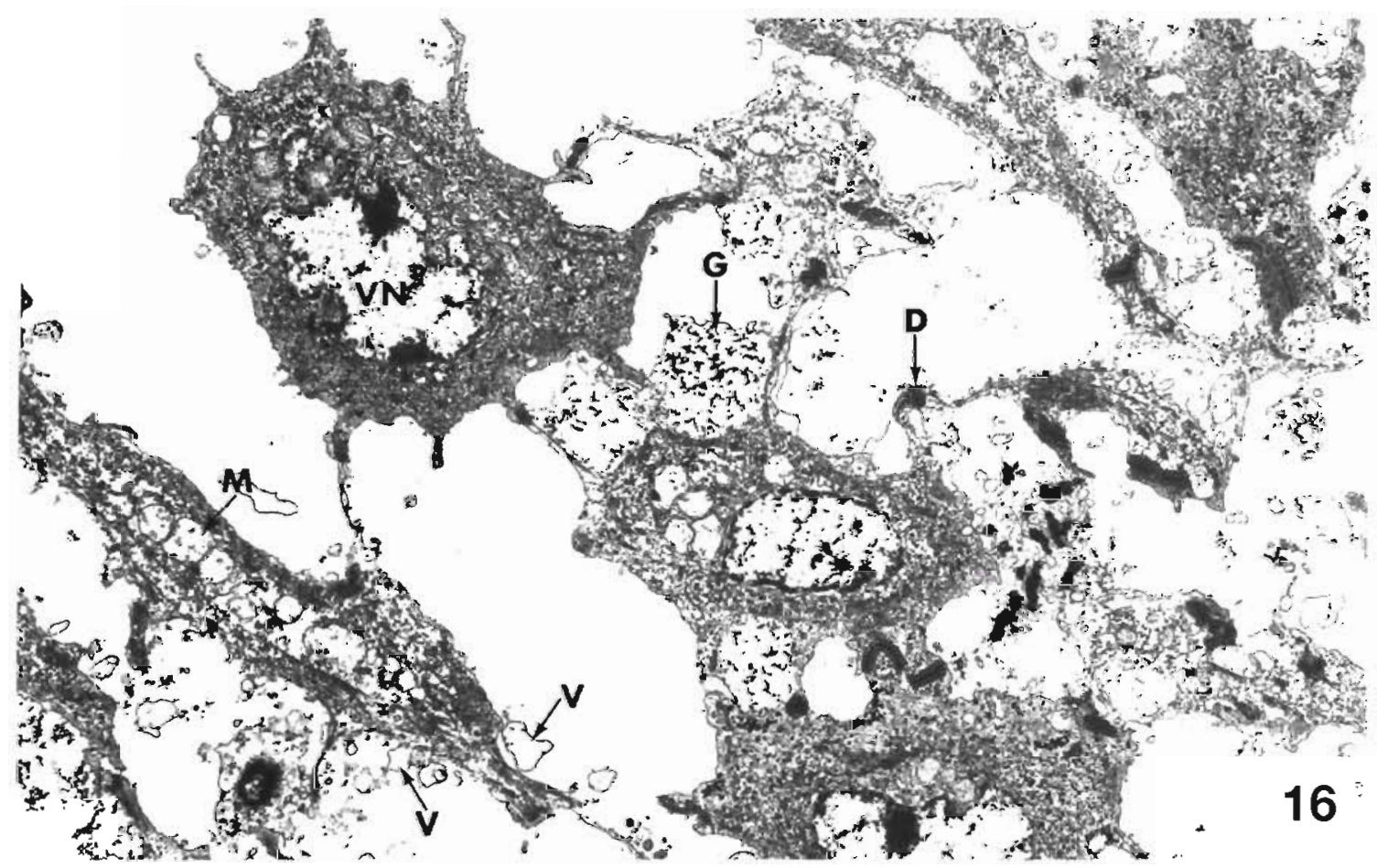

Fig. 16. Electron micrograph of an advanced spongiotic lesion in the middle layer of necrotic, oval-shaped epithelial cells near the fin ray from a fish collected from a contaminated site (New Haven Harbor). Note the vesiculate nuclei (VN), the vesiculations of their plasmalemmae (V), the high amplitude swelling of their mitochondria (M), the loss of glycogen (G) to the intercellular space, and the breakdown of their intercellular junctions. $(D=$ desmosomes $) \times 5278$ 


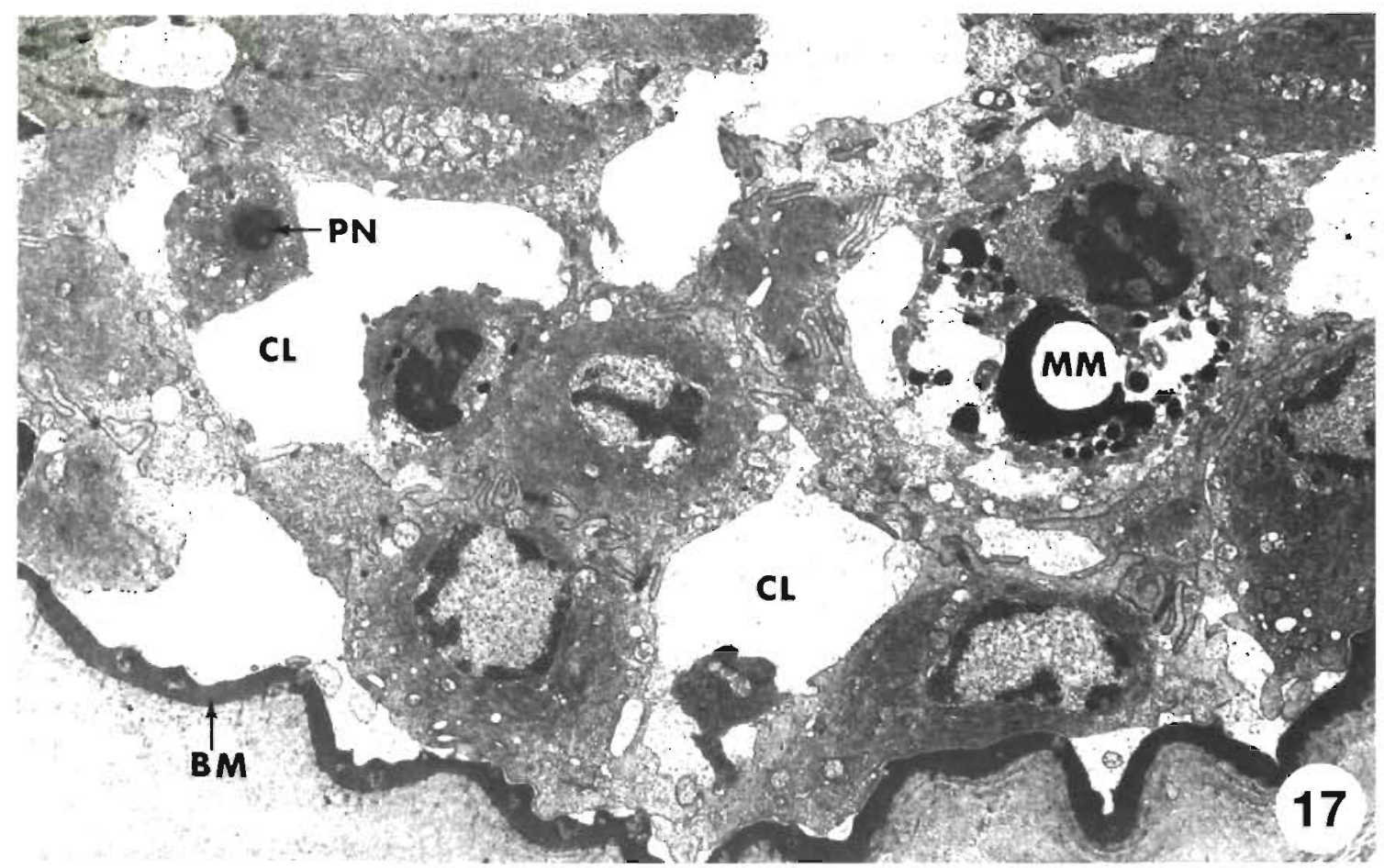

Fig. 17. Electron micrograph of a spongiotic lesion in the thin, inter-ray epidermis found in a fish from a contaminated site (New York Bight). The extensive intercellular space between the degenerating cells has resulted in several cleft-like spaces (CL) within the necrotic tissue. ( $\mathrm{PN}=$ pyknotic nucleus; $\mathrm{MM}=$ melanomacrophage; $\mathrm{BM}=$ basement membrane) $\times 5429$

logical studies of more severe fin erosion lesions in winter flounder (Murchelano 1975), starry flounder and English sole from the Duwamish River Estuary (Wellings et al. 1976), and perch or goldfish exposed to BKME (Lindesjöö \& Thulin 1994). EGCs were observed at various levels within the epithelium but did not appear to be as numerous as reported by Murchelano (1975) or Wellings et al. (1976). As Roberts et al. (1971) have shown for the plaice, melanomacrophages were occasionally observed near the surface of the normal epidermis. Although epidermal papillomas have been widely observed in fish from both polluted and clean environments (Peters 1984, Smith et al. 1989), reports on nonpapillomatus epidermal hyperplasia in feral fish appear much more limited but have been observed in fish from polluted environments (Haensly et al. 1982, Bucke et al. 1983, Bruno \& Ellis 1988, Dethlefsen 1988).

Mucous cells, particularly those found in the delicate tissues of the gill, respond to a wide variety of toxicants and/or irritants by undergoing hyperplasia or hypertrophy. If the noxious stimulus persists, cellular de- pletion may occur (Mallatt 1985). While no attempt was made here to quantitatively study the mucous cells within the fin epithelium of either control or diseased

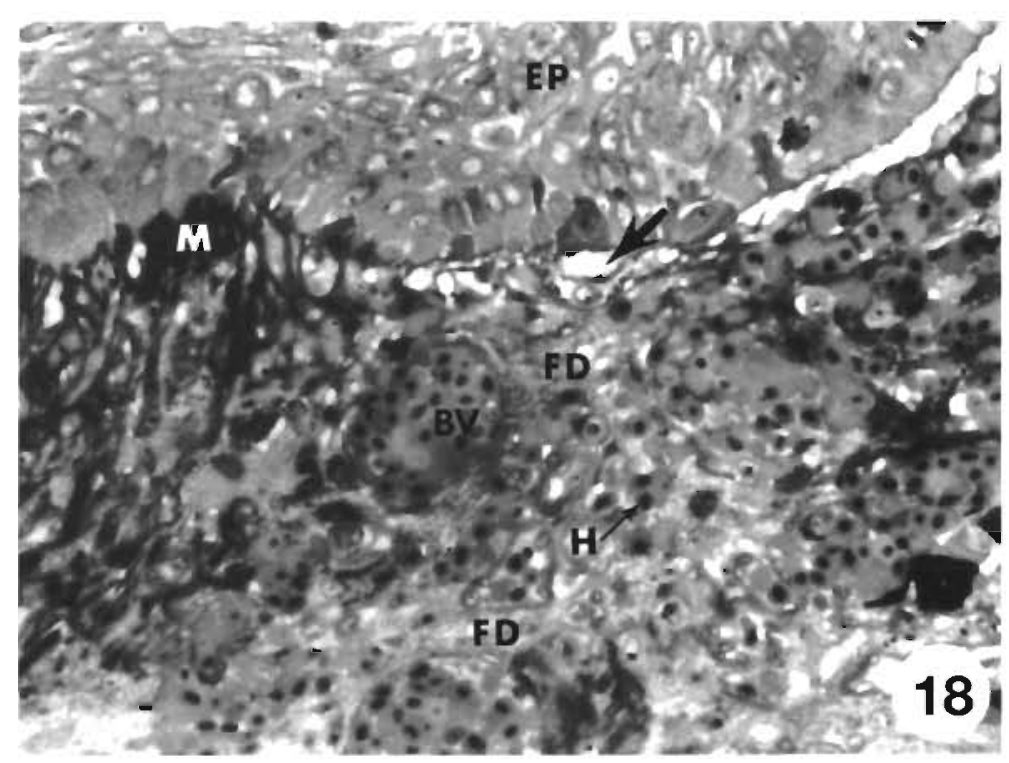

Fig. 18. Photomicrograph of the epidermal-dermal border $(\leftarrow)$ from a fish collected in a contaminated site (New York Bight) illustrating the abnormal aggregation of melanocytes (M) at the junction between the epidermis (EP) and the underlying fibrotic dermis (FD). Congested blood vessels (BV) and hemorrhage $(\mathrm{H})$ were also observed. $\times 364$ 


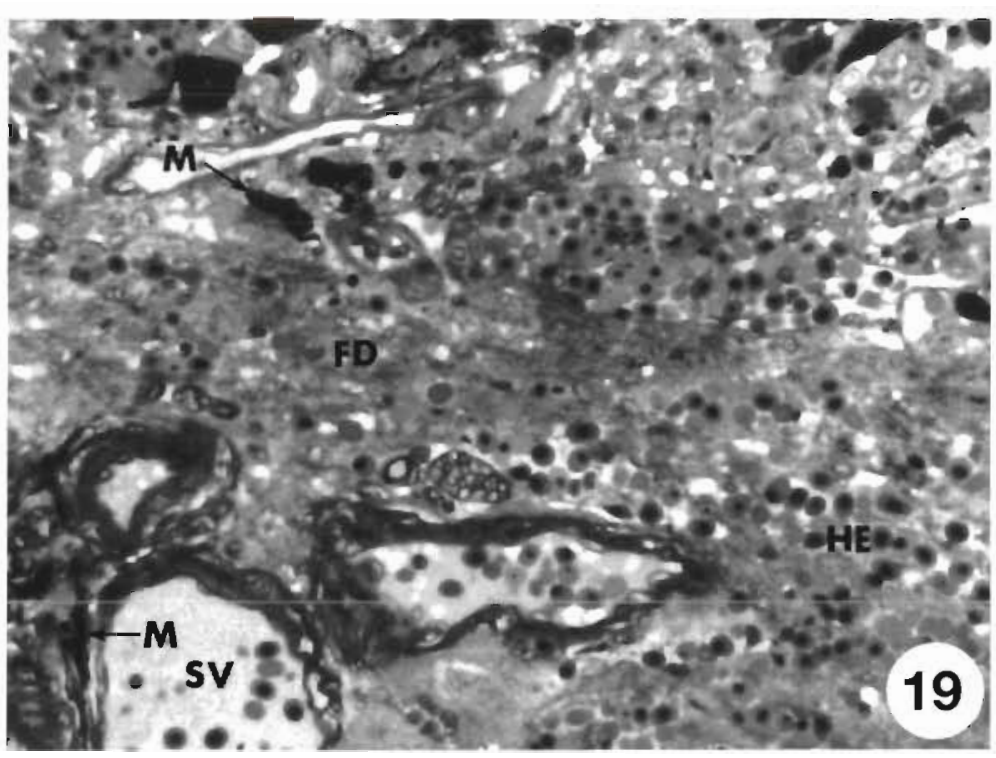

Fig. 19. Photomicrograph of the dermis from the same fish illustrated in Fig 18 but at an adjacent and deeper location. Note the melanocytes (M) within the fibrotic dermis (FD) and in association with the sclerotic blood vessels (SV). Hemorrhage (HE) is also apparent. $\times 364$

specimens, a comparison between mucous cells observed in the control tissue and those found in in some of the diseased specimens suggested that those present in the latter were frequently both hyperplastic and hypertrophic. In addition, the existence of a number of empty mucous cell profiles in the diseased fin tissues indicated that cell depletion may have occurred. These observations are comparable to those of others studying fin erosion in flatfish; Murchelano (1975) described mucous cell hyperplasia in winter flounder, and Wellings et al. (1976) observed both mucous cell hyperplasia and depletion in 2 flatfish species, the starry flounder Platichthys stellatus and English sole Parophrys vetulus from Puget Sound. Mucous cell hyperplasia has also been reported in eroded fins of goldfish Carassius auratus exposed to BKME (Sharples \& Evans 1996), and in English sole exposed to the water soluble fraction of crude oil (Hawkes 1977). Daye \& Garside (1976) observed hypertrophy and excess mucous secretion on the skin of brook trout Salvelinus fontinalis exposed to elevated levels of $\mathrm{pH}$. Mucous cell depletion has been reported in the integument of the brown bullhead Ictalurus nebulosus after long-term exposure to 3 ppm of copper (Benedetti et al. 1989), and in the carp Cyprinus carpio after exposure to organically fertilized pond water (Iger et al. 1988).
Spongiosis or intercellular edema most probably resulting from an inflammatory response of the skin (Roberts \& Bullock 1976, Roberts 1989) was observed in the fin epithelium of winter flounder from both of the contaminated sites. Murchelano (1975) did not mention spongiosis in his histopathological description of fin erosion in winter flounder, nor has it been described by other investigators who have conducted histopathological studies of other feral fish species which had fin erosion disease (Klontz \& Bendele 1973, Wellings et al. 1976, Lindesjöo \& Thulin 1994, Sharples \& Evans 1996). Although spongiosis was not mentioned by Lindesjöö \& Thulin (1994) in their study of goldfish exposed to BKME, it appears to have been present in the epithelium of the fish they studied which had acute fin erosion lesions (e.g., Figs. 17 \& 19).

The pathological changes observed in the dermis as reported herein are in agreement with those found in fin-eroded tissues of both winter flounder (Murchelano 1975) and goldfish (Lindesjöö \& Thulin 1994) and included hemorrhage and blood vessel congestion where epidermal hyperplasia and/or spongiosis was present. Murchelano (1975) was the first to consider the possibility that ischemia resulting from hemorrhage and/or hyperemia in the dermis affected the blood supply to the overlying epithelium in the diseased fins of winter flounder. There is, however, no experimental evidence

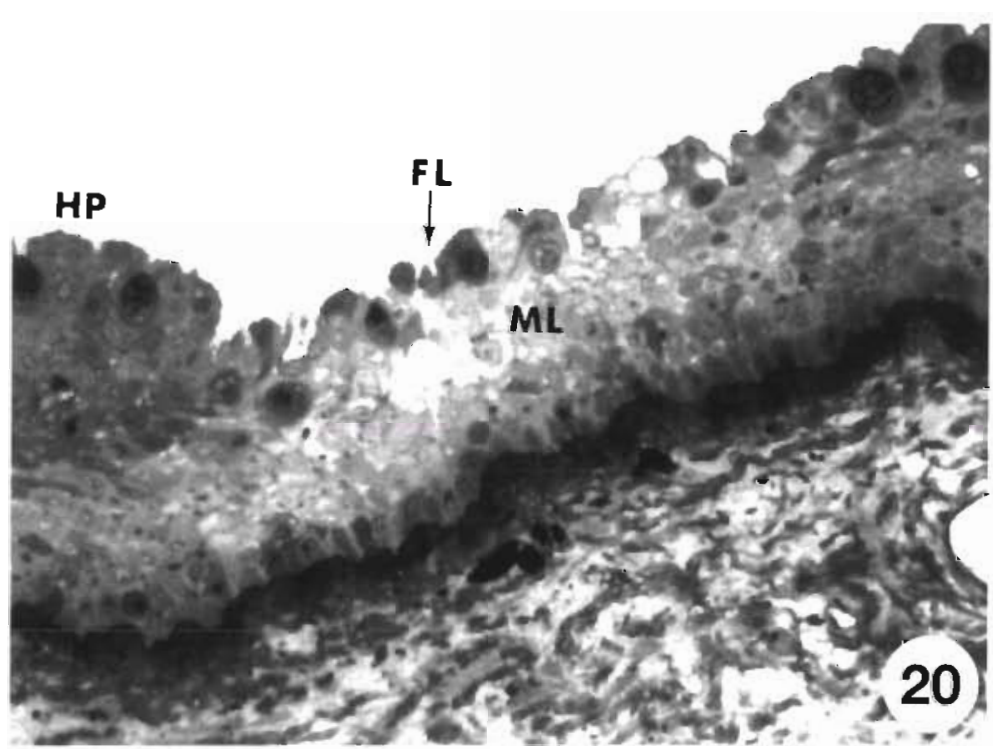

Fig. 20. Photomicrograph of a focal lesion (FL) adjacent to a region of hyperplastic epidermis (HP) in the epithelium close to the fin rays of a fish collected at a contaminated site (New Haven Harbor). The cells at both the epithelial surface and within the middle cell layer (ML) are necrotic. $\times 350$ 


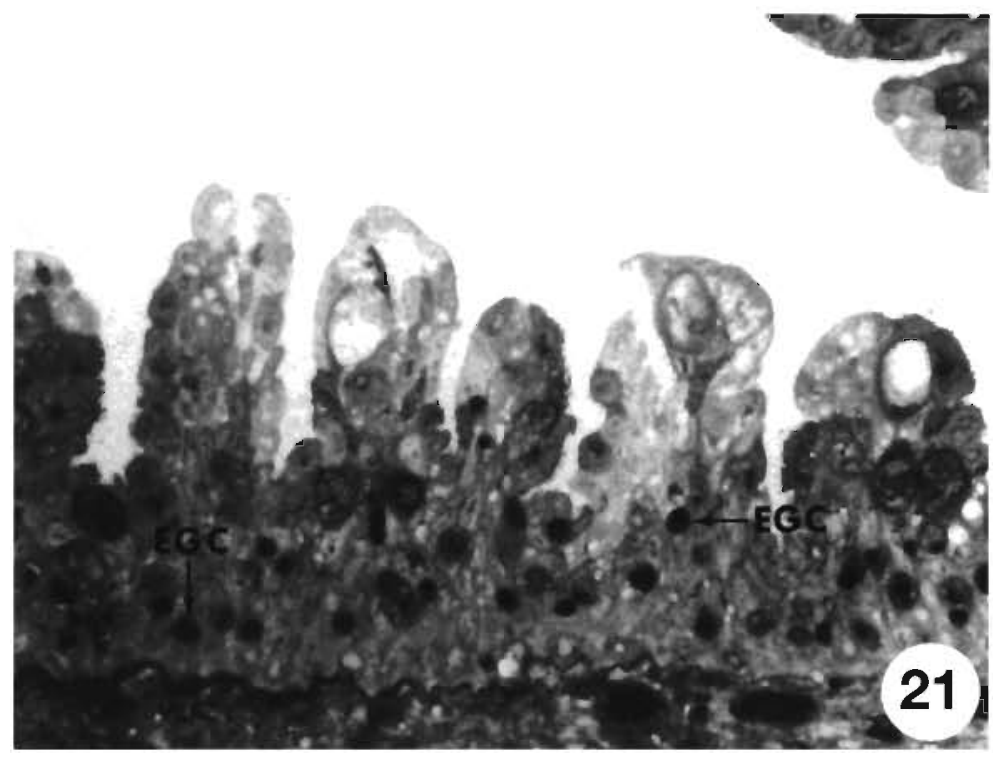

Fig. 21. Photomicrograph of a focal lesion in the inter-ray tissue from a fish captured at a contaminated site (New York Bight). The surface cells are undergoing degeneration and are being sloughed. A number of densely stained eosinophilic granular cells (EGC) are present. $\times 400$

ciated with the focal necrotic lesions or any other type of lesions observed in this study. Lesions in the surface epithelia of fish may result from exposure to a variety of organochlorine (e.g., DDT) and other pesticides (Meyers \& Hendricks 1985), exposure to heavy metals (Gardner 1975, Bodammer 1985, Benedetti et al. 1989), and abnormal levels of environmental $\mathrm{pH}$ (Daye \& Garside 1976).

As is indicated in Table 1, a low percentage of several lesion types was observed in the fin epithelium of fish from the control sites. There are a number of reasons why this may have occurred. Microscopic lesions may have been present in the dorsal fins of fish that did not demonstrate grossly visible lesions. The Great Bay site in southern New Jersey waters served as a control location for the extensive studies being conducted by Murchelano (1975) during the early and mid 1970s because the water and sediment quality of the area was considered to be 'relatively pristine' in

to prove that ischemia is the cause of the pathology observed in the diseased fins of winter flounder. Roberts (1989) has indicated that degenerative changes in epidermis of fish are often the result of a 'vascular change' within the dermis. Therefore, it is possible that hypoxia may have been the cause of the spongiotic condition observed within the epidermis of the fish studied herein. Similarly, Lindesjöö \& Thulin (1994) believe an undefined 'physiological disturbance' may have resulted in the pathological changes in the dermis leading to the necrosis of fin tissues in goldfish exposed to BKME.

Whereas the necrosis and loss of small areas of epithelium were not reported by Murchelano (1975) for eroded fins in winter flounder, Wellings et al. (1976) reported small ulcers of this type in the English sole and starry flounder. Small lesions were prevalent in the fin tissues of fish found at both of our polluted sites. Focal necrosis of the fin tissues was found in areas close to the fin rays or in the skin between them, and unlike the other types of severe or extensive lesions that have been described by others, degeneration and sloughing of surface cells were typically observed. Recently, Sharples \& Evans (1996) described progressive, severe necrosis commencing at the level of the surface epithelium (accompanied by a marked lymphocytic infiltration) as the principal mechanism leading to acute fin erosion disease in feral goldfish exposed to BKME. Unlike the observations by Sharples \& Evans (1996), no marked infiltration of lymphocytes or other types of leucocytes were observed to be asso- comparison with the conditions found in the New York Bight region. However, as the extensive studies of Ziskowski et al. (1987) on the prevalence of fin erosion disease in winter flounder along the northeast coast of the United States have shown, fish from the southern New Jersey coastline, which includes Great Bay, had a low prevalence of fin erosion disease. Therefore, it is possible that the fin tissues of fish collected from Great Bay for this study had some of the microscopic changes associated with fin erosion disease but were undetected for the reason stated above. Although the prevalence of fin erosion disease in winter flounder at the Niantic River control site was not studied by Ziskowski et al. (1987), this site serves as a reproductive area for winter flounder which may have migrated there from various regions in Long Island Sound, where fin erosion disease was observed (Ziskowski et al. 1987). While winter flounder are not considered to be a highly migratory species (Gray 1990), the problem of their possible migration and the relationship of this behavior to fin erosion disease is borne out in the fact that Ziskowski et al. (1987) found, much to their surprise, that the highest prevalence of fin erosion disease in winter flounder was observed in fish captured in the Gulf of Maine, which is not considered to be a 'polluted' area. They hypothesized that the winter flounder from the Gulf of Maine which had fin erosion disease were migrants from 'nearby environmentally stressed estuarine populations'.

Because contaminant concentrations in fish tissues, sediments, or the water column were not investigated 
in the present study, it is not possible to designate a specific contaminant or a combination thereof as the causal factor for the lesions that were observed on the dorsal fins of winter flounder as reported herein. Because fin erosion disease in bottom-dwelling fish has been observed in urban and industrially polluted waters along all coasts of the United States and in sites of poor water quality in Europe, it would seem unlikely that a specific pollutant or identical combinations of pollutants would be found in similar concentrations at the various locations where fin erosion disease has been reported. Given all the etiological possibilities that may exist at the numerous locations where this ubiquitous disease has been observed, it seems safest to assume at this time that fin erosion disease in winter flounder, as well as in other fish species, results from the generalized responses of the fin epithelium and dermis (e.g., hyperplasia, spongiosis, necrosis, dermal fibrosis, hyperemia, etc.) to a potentially wide variety of toxic substances. Thus, the disease appears to remain, as Murchelano (1982) has previously stated, as one of 'uncertain etiology'.

This report is the first in which both light and electron microscopy have been used to examine both the normal and pathological fin tissues in winter flounder which have fin erosion disease. The results obtained from tissues located in close proximity to well-established fin erosion lesions provide general support for the earlier work on winter flounder (Murchelano 1975), other feral flatfish species, and goldfish exposed to BKME (Lindesjöö \& Thulin 1994). No evidence was found in this study for a bacterial or viral etiology for fin erosion disease, and both epidermal and mucous cell hyperplasia observed in the integument of diseased fish were in keeping with the generalized reactions of fish skin to irritants and/or toxic insults. Spongiosis and focal necrotic lesions of limited scope are reported for the first time in winter flounder with fin erosion disease. Vascular and fibrotic changes within the dermis of diseased fish were observed that may be responsible for the breakdown of the normal epidermal-dermal junction, and could thereby precede or initiate further pathologic change in the epithelium owing to hypoxia. A multiplicity of lesion types were found in close proximity to each other in the affected integument, any or all of which could ultimately lead to necrosis of the fin tissue.

Acknowledgements. I wish to thank Mr John Ziskowski for collecting winter flounder at Great Bay, NJ, and New Haven Harbor, CT. Similarly, I wish to thank Dr Donald Danilla and the staff at the Millstone Nuclear Power Plant, Waterford, CT, for collecting winter flounder from the Niantic River, CT The manuscript benefitted from the critical reviews of Drs R. A. Robohm, A. Calabrese, R. A. Murchelano, R. E. Wolke, Mr
Mark Myers, and other anonymous reviewers. Thanks is also given to Ms Debra Spitzer for her technical assistance.

\section{LITERATURE CITED}

Alexander JB, Ingram GA (1992) Noncellular defence mechanisms of fish. Annu Rev Fish Dis 2:249-279

Becerra J, Montes GS, Bexiga SRR, Junqueira LCU (1983) Structure of the tail fin in teleosts. Cell Tissue Res 230: $127-137$

Benedetti I, Albano AG, Mola L (1989) Histomorphological changes in some organs of the brown bullhead, Ictalurus nebulosus LeSueur, following short- and long-term exposure to copper. J Fish Biol 34:273-280

Bodammer JE (1985) Corneal damage in larvae of striped bass Morone saxatilis exposed to copper. Trans Am Fish Soc 114:577-583

Brandstätter R, Misof B, Pazmandi C, Wagner, GP (1990) Micro-anatomy of the pectoral fin in blennies (Blennini, Blennioidea, Teleostei). J Fish Biol 37:729-743

Bruno DW, Ellis AE (1988) Histopathological effects in Atlantic salmon, Salmo salar L., attributed to the use of tributyltin antifoulant. Aquaculture 72:15-20

Bucke D, Feist SW, Norton MG, Rolfe, MS (1983) A histopathological report of some epidermal anomalies of Dover sole, Solea solea $L_{1}$, and other flatfish species in coastal waters off south-east England. J Fish Biol 23:565-578

Bullock AM, Roberts RJ (1974) The dermatology of marine teleost fish. I. The normal integument. Oceanogr Mar Biol Annu Rev 13:383-411

Clark G (1981) Miscellaneous methods. In: Clark G (ed) Staining procedures, Chap. 7. Williams and Wilkens, Baltimore, p 171-215

Daye PG, Garsicie ET (1976) Histopathologic changes in surficial tissues of brook trout, Salvelinus fontinalis (Mitchell), exposed to acute and chronic levels of $\mathrm{pH}$. Can J Zool $54: 2140-2155$

Dethlefsen V (1988) Status report on aquatic pollution problems in Europe. Aquat Toxicol 11:259-286

Ellis AE (1985) Eosinophilic granular cells (EGC) and histamine responses to Aeromonas salmonicida toxins in rainbow trout. Dev Comp Immunol 9:251-260

Gardner GR (1975) Chemically induced lesions in estuarine or marine teleosts. In: Ribelin WE, Migaki G (eds) Pathology of fishes, Chap. 27. University of Wisconsin Press, Madison, p $657-693$

Gray CL (1990) Winter flounder Pseudopleuronectes americanus. Species Profile, Rhode Island Department of Environmental Management, Division of Fish and Wildlife, Marine Fisheries Division, p 7-8

Greig RA, Sennefelder G (1987) PCB concentrations in winter flounder from Long Island Sound, 1984-1986. Bull Environ Contam Toxicol 39:863-868

Greig RA, Reid RN, Wenzloff DR (1977) Trace metal concentrations in sediments from Long Island Sound. Mar Pollut Bull 8:183-188

Gronlund WD, Chan S, McCain BB, Clark RC, Myers MS, Stein JE, Brown DW, Landahl JT, Krahn MM, Varanasi U (1991) Multidisciplinary assessment of pollution at three sites in Long Island Sound. Estuaries 14:299-305

Haensly WE, Neff JM, Sharp JR, Morris AC, Bedgood MF, Boehm PD (1982) Histopathology of Pleuronectes platessa L. from Aber Wrac'h and Aber Benoit, Britanny, France: long-term effects of the Amoco Cadiz crude oil spill. J Fish Dis 5:365-391

Hawkes JW (1977) The effects of petroleum hydrocarbon 
exposure on the structure of fish tissues. In: Wolfe DA (ed) Fate and effects of petroleum hydrocarbons in marine ecosystems and organisms, Chap 10. Pergamon Press, New York, p 115-128

Iger $Y$, Abraham M, Dotan A, Fattal B, Rahamim E (1988) Cellular responses in the skin of carp maintained in organically fertilized water. J Fish Biol 33:711-720

Johnson LL, Stehr CM, Olson OP, Myers MS, Pierce SM, Wigren CA, McCain BB, Varanasi U (1993) Chemical contaminants and hepatic lesions in winter flounder (Pseudopleuronectes americanus) from the northeast coast of the United States. Environ Sci Technol 27:2759-2771

Khan RA, Barker D, Hooper R, Lee EM (1992) Effect of pulp and paper effluent on a marine fish, Pseudopleuronectes americanus. Bull Environ Contam Toxicol 48:449-456

Klontz GW, Bendele RA (1973) Histopathological analysis of fin erosion in southern California marine fishes. Southern Calif. Coastal Water Res Proj El Segundo Calif Rep TM 203

Lanzing WJR (1976) The fine structure of fins and finrays of Tilapia mossambica (Peters). Cell Tissue Res 173:349-356

Lindesjöö E. Thulin J (1994) Histopathology of skin and gills of fish in pulp mill effluents. Dis Aquat Org 18:81-93

Mallatt J (1985) Fish gill structural changes induced by toxicants and other irritants: a statistical review. Can J Fish Aquat Sci 42:630-648

McCain BB, Brown DW, Krahn MM, Myers MS, Clark RC Jr, Chan SL, Malins DC (1988) Marine pollution problems, North American West Coast. Aquat Toxicol 11:143-162

Meyers TR, Hendricks JD (1985) Histopathology. In: Rand GM, Petrocelli SR (eds) Fundamentals of aquatic toxicology, Chap 11. New York Hemisphere Publishing Corp, New York, p 283-331

Murchelano RA (1975) The histopathology of fin rot disease in winter flounder from the New York Bight. J Wildl Dis 11: $263-268$

Murchelano RA (1982) Some pollution-associated diseases and abnormalities of marine fishes and shellfishes: a perspective for the New York Bight. In: Mayer GF (ed) Ecological stress and the New York Bight: science and management. Estuarine Research Federation, Columbia, p $327-346$

Murchelano RA, Wolke RE (1985) Epizootic carcinoma in winter flounder, Pseudopleuronectes americanus. Science 228:587-589

Murchelano RA, Ziskowski JJ (1982) Fin rot disease in the New York Bight (1973-1977). In: Mayer GF (ed) Ecological stress and the New York Bight: science and management. Estuarine Research Federation, Columbia, p 347-358

O'Connor JM, Huggett RJ (1988) Aquatic pollution problems, North Atlantic coast, including Chesapeake Bay. Aquat Toxicol 11:163-190

O'Connor JM, Rachlin JW (1982) Perspectives on metals in New York Bight organisms: factors controlling accumulation and body burdens. In: Mayer GF (ed) Ecological stress and the New York Bight: science and management. Estuarine Research Federation, Columbia, p 655-673

O'Connor JM, Klotz JB, Kneip TJ (1982) Sources, sinks, and distribution of organic contaminants in the New York Bight ecosystem. In: Mayer GF (ed) Ecological stress and the New York Bight: science and management. Estuarine Research Federation, Columbia, p 631-655

Overstreet RM (1988) Aquatic pollution problems, southeastern U.S. coasts: histopathological indicators. Aquat Toxicol 11:213-239
Peleteiro MC, Richards RH (1985) Identification of lymphocytes in the epidermis of the rainbow trout, Salmo gairdneri Richardson. J Fish Dis 8:161-172

Peters N (1984) Diseases caused by neoplasia. In: Kinne O (ed) Diseases of marine animals, Vol IV, Part 1. Pisces, Biologische Anstalt Helgoland, Hamburg, p 400-423

Powell MD, Wright GM, Burka JF (1991) Degranulation of eosinophilic granule cells induced by capsaicin and substance $\mathrm{P}$ in the intestine of rainbow trout (Onchorhynchus mykiss Walbaum). Cell Tissue Res 266:469-474

Roberts RJ (1989) The pathophysiology and systemic pathology of teleosts. In: Roberts RJ (ed) Fish pathology, Chap 3. Bailliere Tindall, London, p 56-134

Roberts RJ, Bullock AM (1976) The dermatology of marine teleost fish. II. Dermatopathology of the integument. Oceanogr Mar Biol Annu Rev 14:227-246

Roberts RJ, Young H, Milne JA (1971) Studies on the skin of plaice (Pleuronectes platessa L.). I. Structure and ultrastructure of normal plaice skin. J Fish Biol 4:87-98

Robertson A, Gottholm BW, Turgeon DD, Wolfe DA (1991) A comparative study of contaminant levels in Long Island Sound. Estuaries 14:290-298

Sharples AD, Evans CW (1996) Pathology of fin erosion in goldfish Carassius auratus. Dis Aquat Org 24:81-91

Singh SK, Mittal AK (1990) A comparative study of the epidermis of the common carp and three Indian major carp. J Fish Biol 36:9-19

Smith IR, Ferguson HW, Hayes MA (1989) Histopathology and prevalence of epidermal papillomas epidemic in brown bullhead, Ictalurus nebulosus (Lesueur), and white sucker Catostomus commersoni (Lacepede), populations from Ontario, Canada. J Fish Dis 12:373-388

Spurr AR (1969) A low viscosity epoxy resin embedding medium for electron microscopy. J Ultrastruct Res 26: $31-43$

Turgeon DD, O'Connor TP (1991) Long Island Sound distributions, trends, and effects of chemical contamination. Estuaries 14:279-289

Vethaak AD (1987) Fish diseases. Signals for a diseased environment? In: Peet G (ed) Proc 2nd North Sea Seminar '86, reasons for concern. Werkgroep Nordzee, Amsterdam

Wellings SR, Alpers CE, MCCain BB, Miller BS (1976) Fin erosion disease of starry flounder (Platichthys stellatus) and English sole (Parophrys vetulus) in the estuary of the Duwamish River, Seattle, Washington. J Fish Res Board Can 33:2577-2586

Whitear M (1986a) Chap 2. Epidermis. In: Matoltsky AG, Richards KS, Bereiter-Hahn J (eds) The skin of fishes including cyclostomes. II. Biology of the integument. Springer-Verlag, Heidelberg, p 8-38

Whitear M (1986b) Chap 3. Dermis. In: Matoltsky AG, Richards KS, Bereiter-Hahn J (eds) The skin of fishes including cyclostomes. II. Biology of the integument. Springer-Verlag, Heidelberg, p 40-64

Whitear M, Mittal AK (1984) Surface secretions of the skin of Blennius (Lipophrys) pholis L. J Fish Biol 25:317-331

Zdanowicz VS, Gadbois DF, Newman MW (1986) Levels of organic and inorganic contaminants in sediments and fish tissues and prevalences of pathological disorders in winter flounder from estuaries of the northeast United States, 1984. In: Proc Oceans '86. IEEE, Washington, DC, p 578-585

Ziskowski JJ, Despres-Patanjo L, Murchelano RA, Howe AB, Ralph D, Atran S (1987) Disease in commercially valuable fish stocks in the northwest Atlantic. Mar Pollut Bull 18: 496-504

Submitted: September 15, 1997; Accepted: November 11, 1999 Proofs received from author(s): February 10, 2000 